\section{La responsabilidad del continuum educativo en la formación de los médicos}

Entre las diferentes actividades desarrolladas en el XVIII Congreso de la SEDEM destacó una mesa redonda sobre la responsabilidad del continuum educativo y muy especialmente entre la formación de grado que realiza la universidad y la formación especializada que realiza el sistema sanitario.

Si hemos de hacer caso al aforismo que dice "de aquellos barros vinieron estos lodos" no debemos extrañarnos que actualmente exista una desconexión entre los dos periodos de formación reglados que siguen los médicos, el grado y la especialidad. Antes del actual sistema MIR la formación especializada se realizaba en la universidad con un resultado que no cubría los mínimos exigibles. El desplazamiento de la formación especializada desde la universidad hacia el sistema sanitario, en su momento traumático, ha dado unos frutos tan espectaculares que hoy son reconocidos por todos y por tanto hay que reconocer el acierto de haber tomado dicha decisión. Pero las mejores decisiones no están exentas de problemas. Así, se perdió el cordón lógico de enlace entre dos periodos de formación contiguos.

¿Cuantas veces hemos oído, como punto débil del sistema de formación de especialistas, que el examen MIR condiciona la formación de grado? Si la formación de grado estuviera coordinada con la formación especializada esta crítica se convertiría en un punto fuerte. Todos los participantes en la mesa redonda, estudiantes de medicina, estudiantes de especialidad, las facultades de medicina, el CNE, y la propia administración tanto sanitaria como de educación estuvieron de acuerdo en la necesidad de establecer algún puente, permanente y estable, de coordinación entre el grado y la formación especializada.

Desde el mundo académico que representa la Sociedad Española de Educación Médica y la Fundación Educación Médica solo nos queda formular una pregunta ¿para cuando un puente sólido, estable con responsabilidades y deberes entre el grado y la formación de especialistas? Nosotros lamentamos no poder contestar ya que la respuesta entra en las responsabilidades políticas pero soñamos que alguien en algún lugar y en algún momento tomara decisiones al respecto.

\section{The responsibility to develop an educational continuum in the training of doctors}

Among the various activities which took place as part of the XVIII Congress of the Spanish Society for Medical Education (SEDEM), particular attention should be paid to a round table on the responsibility to develop an educational continuum, especially between the undergraduate training offered by the universities and the specialist training received within the health service.

If it is true that we reap what we sow then it should come as no surprise that there is currently a poor link between the two periods of training that doctors are obliged to complete: their medical degree and their specialist training. Prior to the current MIR system for medical interns, specialist training was offered by the universities, the result being that it did not meet minimum requirements. Although it proved to be an upheaval at the time, the decision to shift specialist training from the universities to the health service has borne such abundant fruit that the wisdom of that decision is now accepted by everyone. Nevertheless, not even the best of decisions are free of problems, and in this case the problem has been the loss of a clear link between two successive periods of training.

How many times has it been said that the weak point in the training of specialists is that the MIR exam overshadows and has an undue influence on undergraduate studies? However, if undergraduate studies were coordinated with specialist training then this criticism would become the basis of a strength. All those participating in the round table - medical students, interns, medical faculties, the National Council Health Sciences Specilaties (CNE), and representatives of the health and education ministries - agreed on the need to build a permanent and sturdy bridge that would provide a coordinated link between undergraduate and specialist training.

From the academic world represented by the Spanish Society for Medical Education and the Foundation for Medical Education, what remains to be asked is: what is the completion date for this sturdy bridge, one built on responsibilities and duties and able to link the undergraduate and specialist training of doctors? Unfortunately, we are unable to provide an answer as the response lies in the hands of politicians. Thus, all we can do is hope that somebody, somewhere, someday will make the necessary decisions. 